\title{
Genetic Variability and Population Structure of Salvia lachnostachys: Implications for Breeding and Conservation Programs
}

\author{
Marianna Erbano ${ }^{1}$, Guilherme Schnell e Schühli ${ }^{2}$ and Élide Pereira dos Santos ${ }^{3, *}$ \\ 1 Programa de Pós-Graduação em Ciências Farmacêuticas, Universidade Federal do Paraná, \\ 80210-170 Curitiba, Paraná, Brazil; E-Mail: mariannaer@yahoo.com \\ 2 Embrapa Florestas, 83411-000 Colombo, Paraná, Brazil; E-Mail: schuhli@gmail.com \\ 3 Departamento de Botânica, Setor de Ciências Biológicas, Universidade Federal do Paraná, \\ 81530-900 Curitiba, Paraná, Brazil \\ * Author to whom correspondence should be addressed; E-Mail: elide@ufpr.br; \\ Tel./Fax: +55-41-3266-2042.
}

Academic Editor: Marcello Iriti

Received: 8 January 2015 / Accepted: 20 March 2015 / Published: 8 April 2015

\begin{abstract}
The genetic diversity and population structure of Salvia lachnostachys Benth were assessed. Inter Simple Sequence Repeat (ISSR) molecular markers were used to investigate the restricted distribution of S. lachnostachys in Parana State, Brazil. Leaves of 73 individuals representing three populations were collected. DNA was extracted and submitted to PCR-ISSR amplification with nine tested primers. Genetic diversity parameters were evaluated. Our analysis indicated $95.6 \%$ polymorphic loci (stress value 0.02 ) with a 0.79 average Simpson's index. The Nei-Li distance dendrogram and principal component analysis largely recovered the geographical origin of each sample. Four major clusters were recognized representing each collected population. Nei's gene diversity and Shannon's information index were 0.25 and 0.40 respectively. As is typical for outcrossing herbs, the majority of genetic variation occurred at the population level (81.76\%). A high gene flow $(\mathrm{Nm}=2.48)$ was observed with a correspondingly low fixation index. These values were generally similar to previous studies on congeneric species. The results of principal coordinate analysis (PCA) and of arithmetic average (UPGMA) were consistent and all three populations appear distinct as in STRUCTURE analysis. In addition, this analysis indicated a majority intrapopulation genetic variation. Despite the human pressure on natural populations our study found high levels of genetic diversity for S. lachnostachys. This
\end{abstract}


was the first molecular assessment for this endemic species with medicinal proprieties and the results can guide for subsequent bioprospection, breeding programs or conservation actions.

Keywords: intraspecific diversity; ISSR; Labiatae; Southern Brazil

\section{Introduction}

The main centers of diversity for the genus Salvia L. (Lamiaceae) are in Southwest Asia and the Americas, Central and South America [1]. In Brazil, Salvia is mostly found in the Midwest, Southeast and South [2]. Representatives of this genus are used in folk medicine, such as Salvia miltiorrhiza Bunge which is used for the treatment of cardiovascular diseases [3]. Indeed, some species of Salvia have clear pharmacological properties, including, anti-inflammatory [4], gastroprotective [5], antiplatelet and antithrombotic effects [6]. Essential oils and terpenoids are abundant, and represent the principal chemical components in Salvia species [7].

One of the most geographically restricted species is Salvia lachnostachys Benth., a perennial native herb found mainly in Paraná State, southern Brazil [8,9]. Studies with the essential oil from the flowers and leaves of this species indicate the presence of saturated aliphatic compounds and a sesquiterpene fraction [10]. In the hexane fraction of dried, minced leaves, two hydrated triterpene acids (ursolic acid and oleanolic acid) and a norditerpene called fruticulin A were found [9]. The ethanolic extract and fruticulin A from the leaves of Salvia lachnostachys showed have anti-inflammatory and the analgesic effects in oedema, pleurisy, and hyperalgesia induced by carrageenan models in mice [11].

One of the most common methods to study genetic structure and variance in geographically restricted species such as $S$. lachnostachys is through molecular markers. A commonly used technique is inter-simple sequence repeats (ISSRs), which employs the polymerase chain reaction (PCR) and microsatellite sequences to generate multilocus markers with a high degree of reproducibility [12]. Some of the advantages related to this technique include low costs and the possibility of implementation without prior knowledge of the plant genome [13,14]. Moreover, ISSR is accessible to most molecular biology labs and, therefore, has been widely employed in the analysis of genetic variability. Several studies using this technique have been published generally aimed at informing conservation actions $[15,16]$, or for pharmacognostics and authentication [17,18].

Given the dramatic and ongoing threats to Brazil's wildlife and natural landscapes [19], there is an urgent need to assess the diversity and viability of natural populations, especially those that have economic potential. In this context, S. lachnostachys is a prime candidate for analysis of population level genetic variability, being a native species with great medicinal potential and a highly restricted geographic distribution.

\section{Results}

The ISSR analysis produced 10 to 22 amplified bands per primer with an average of 17.6 polymorphic fragments (Figure 1, Table 1). Out of the 159 amplified bands, 152 were polymorphic. The scored fragment sizes ranged from 250 to $2200 \mathrm{bp}$. Estimates of precision based on 159 loci revealed 
high correlation values reaching 0.39 with 10 loci, 0.87 with 80 and 0.99 with 150 . The stress value with 150 loci was 0.02 (values under 0.05 indicates good sample sufficiency based on Kruskal's goodness-of-fit index). The percentage of polymorphic bands ranged from $86 \%$ to $100 \%$, $(95.6 \%$ average). Simpson's index of each primer ranged from 0.66 to 0.86 (0.79 average). In general, dinucleotide repeats $(\mathrm{AG})_{8} \mathrm{YC}$ and $(\mathrm{AG})_{8} \mathrm{~A}$, showed the highest polymorphism.

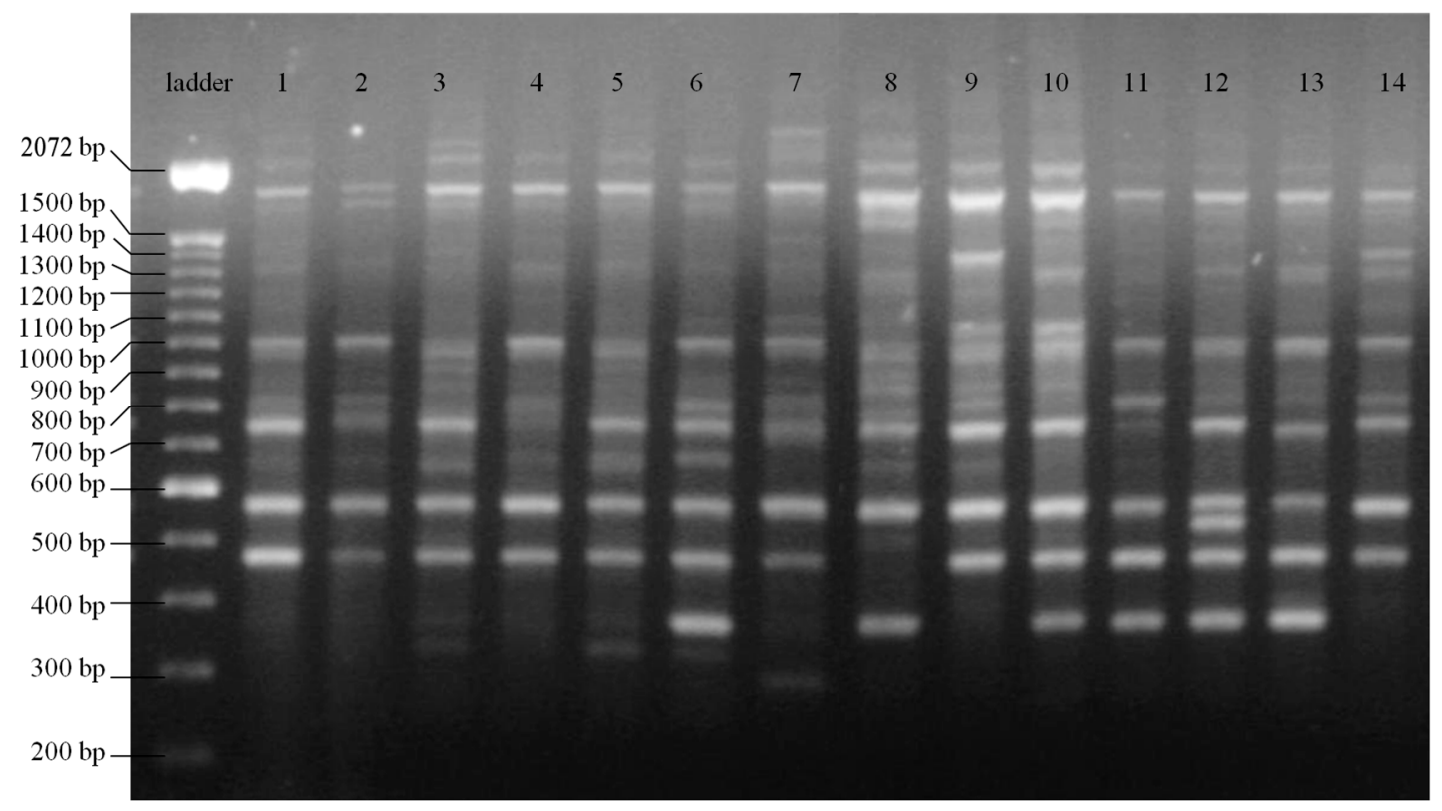

Figure 1. Inter Simple Sequence Repeat (ISSR) profiles of Salvia lachnostachys Benth. collected in Paraná State, Brazil, obtained with primer (CTC) ${ }_{4} \mathrm{RC}$, first lane: marker of 100 bp DNA ladder (Invitrogen), lanes 1-8 from Curitiba; 9-14 from São Luiz do Purunã.

Table 1. ISSR primers used in the analysis of Salvia lachnostachys Benth. (Lamiaceae).

\begin{tabular}{ccccccc}
\hline Sequence $\left(\mathbf{5}^{\prime} \rightarrow \mathbf{3}^{\prime}\right)$ & $\mathbf{A T}\left({ }^{\circ} \mathbf{C}\right)$ & NB & NPB & PPB (\%) & Simpson's Index & Reference \\
\hline$(\mathrm{AC})_{8} \mathrm{~T}$ & 51.4 & 14 & 13 & 93 & 0.79 & {$[20]$} \\
$(\mathrm{AG})_{8} \mathrm{~A}$ & 46.7 & 12 & 11 & 92 & 0.84 & {$[20,21]$} \\
$(\mathrm{AG})_{8} \mathrm{C}$ & 48.8 & 20 & 20 & 100 & 0.83 & {$[22]$} \\
$(\mathrm{AG})_{8} \mathrm{YC}$ & 50.2 & 22 & 22 & 100 & 0.86 & {$[20]$} \\
$(\mathrm{AG})_{8} \mathrm{YT}$ & 49.2 & 19 & 19 & 100 & 0.77 & {$[21,22]$} \\
$(\mathrm{CA})_{8} \mathrm{G}$ & 51.0 & 19 & 19 & 100 & 0.78 & {$[20,21]$} \\
$(\mathrm{CT})_{8} \mathrm{~A}$ & 44.7 & 10 & 10 & 100 & 0.66 & {$[21]$} \\
$(\mathrm{CTC})_{4} \mathrm{RC}$ & 51.7 & 22 & 19 & 86 & 0.77 & {$[20,21]$} \\
$(\mathrm{GA})_{8} \mathrm{~T}$ & 45.4 & 21 & 19 & 90 & 0.80 & {$[20-22]$} \\
Total & - & 159 & 152 & 96 & 0.79 & - \\
Average & - & 17.6 & - & - & - & - \\
\hline
\end{tabular}

$\mathrm{AT}=$ annealing temperature; $\mathrm{NB}=$ numbers of bands; $\mathrm{NPB}=$ numbers of polymorphic bands; $\mathrm{PPB}=$ percentage of polymorphic bands; $\mathrm{Y}=\mathrm{C}$ or $\mathrm{T}, \mathrm{R}=\mathrm{A}$ or $\mathrm{G}$.

Cluster analysis generated a tree (Figure 2A) and a dendrogram (Figure 2B) in which the geographical precedence of each sample is falls into one of four major clusters. The topology suggests a group with individuals from Curitiba (individuals 1-23); Palmeira (31-38 and 24-44); and São Luiz do 
Purunã (48-73). The genetic relationship of individual accessions was analyzed using principal component analysis (PCA). PCA analysis (Figure 3) allowed the identification of the geographical origin of the respective populations.

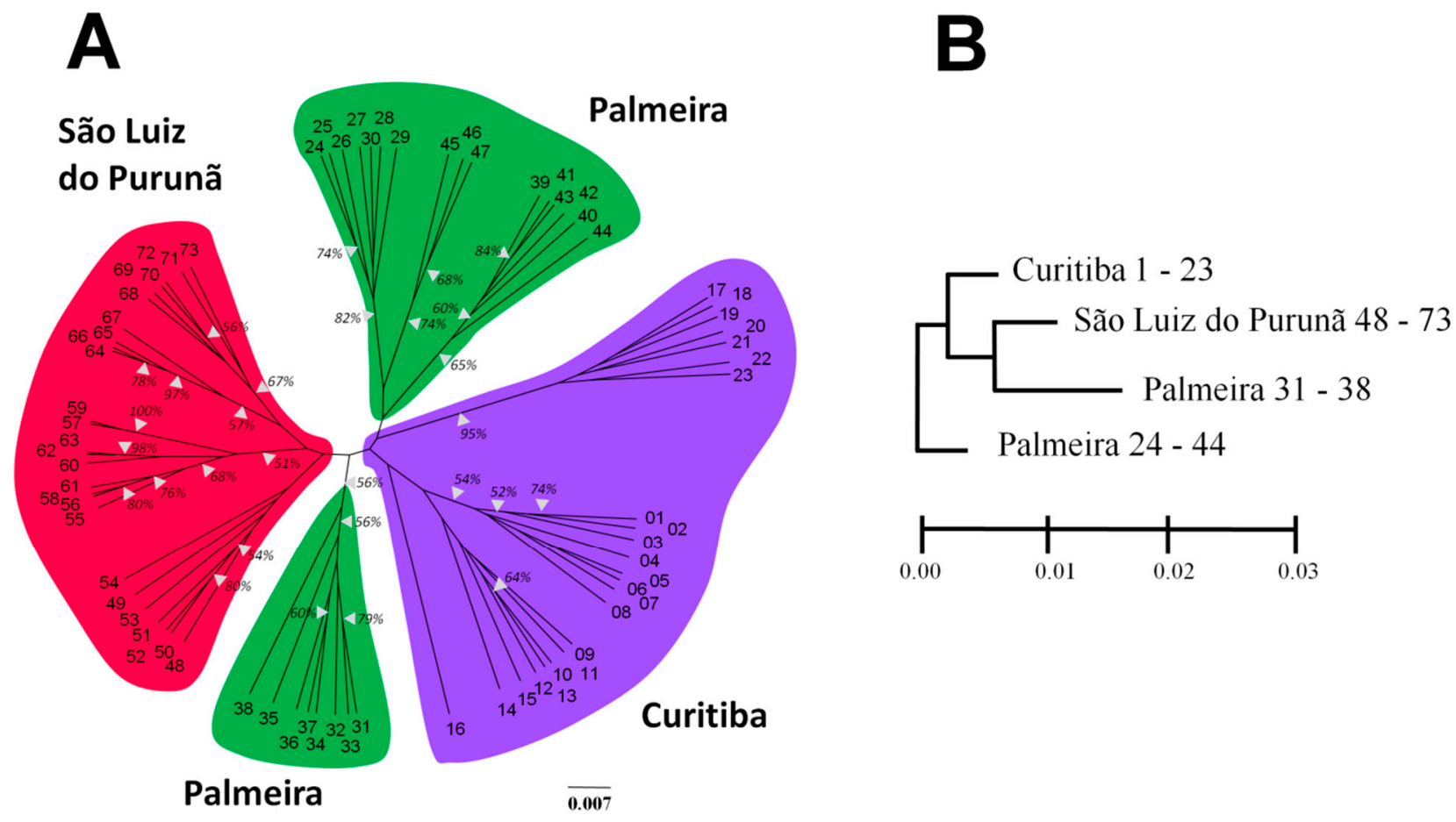

Figure 2. Genetic relationships of three populations of Salvia lachnostachys Benth. based on ISSR markers. (A) Unweighted Pair-group Method using Arithmetic average (UPGMA) unrooted tree illustrating genetic relationships among 73 individuals of $S$. lachnostachys analyzed with 159 loci obtained with PCR/ISSR. The geographical origin is indicated by different colors. Bootstrap support percentages of higher than 50\% are given (10,000 replicates); (B) Collapsed UPGMA tree depicting relationships among populations. Samples included are indicated after population name.

A summary of the ISSR data from each population of S. lachnostachys are given in Table 2 . The percentage of polymorphic bands ranged from $69.81 \%$ to $81.76 \%,(97.48 \%$ average). The observed number of alleles per locus (Ao) and expected number of alleles (Ae) were 1.70 to 1.82 and from 1.33 to 1.39 , respectively. Nei's gene diverstity $(H)$ and Shannon's information index $(I)$ of different geographic groups ranged from 0.20 to 0.24 and from 0.31 to 0.37 , respectively. The group of samples from Curitiba showed the highest genetic variability while the group from São Luiz do Purunã showed the lowest.

The analysis of molecular variance (AMOVA) indicated that the majority of genetic variation occurred at the population level. The genetic differentiation among populations was $16.8 \%\left(G_{s t}=0.1678\right)$, and within populations was $81.76 \%$. Gene flow $(\mathrm{Nm}=2.48)$ indicated low genetic differentiation among populations, and therefore, corroborates a low value for $F_{s t}=0.18$.

S. lachnostachys in the study populations has a heterogeneous genetic structure (Figure 4). The Palmeira population is the most variable among the three populations, while the Curitiba and São Luiz do Purunã populations are the most conservative. 


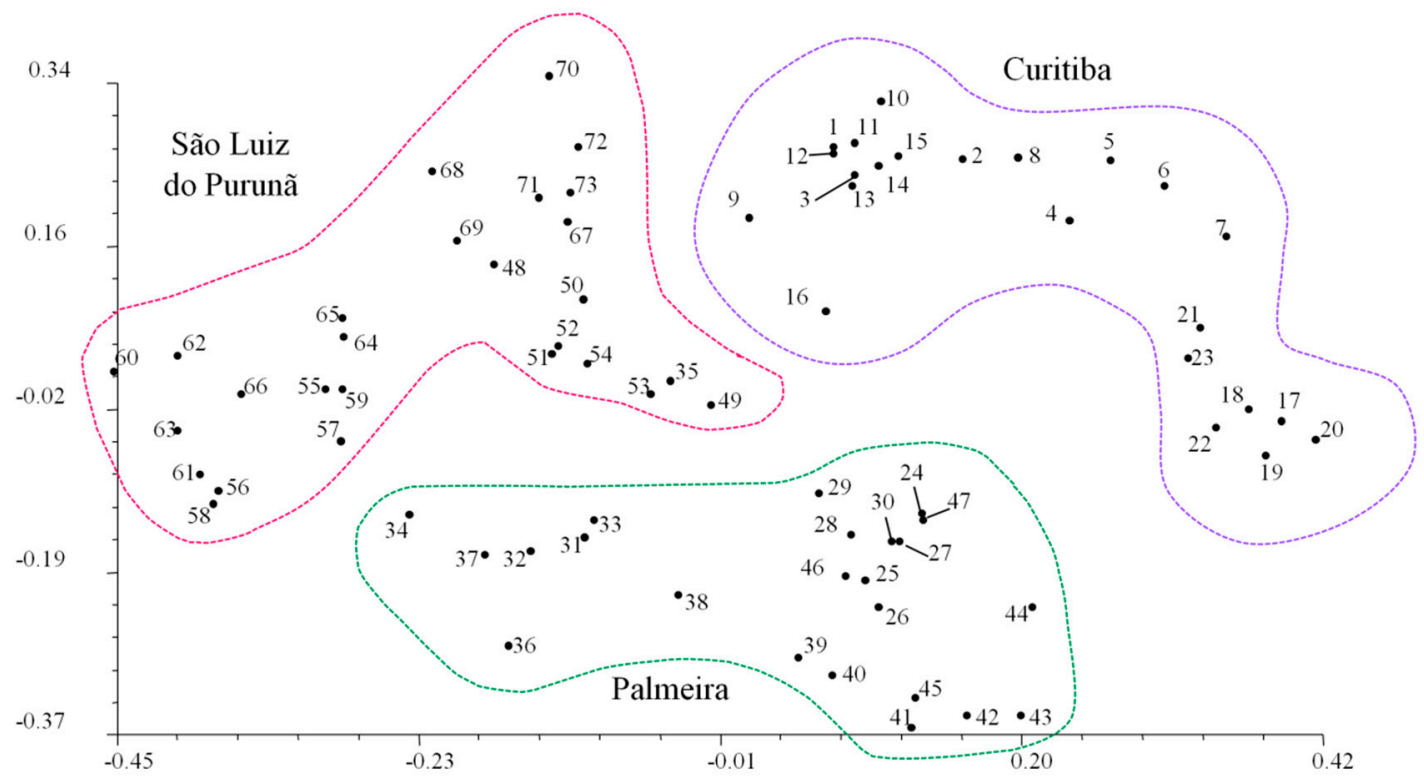

Figure 3. Principal components analysis from 73 individuals of S. lachnostachys collected on three locations in the Parana State, Brazil.

Table 2. Genetic diversity of three populations of Salvia lachnostachys Benth. (Lamiaceae).

\begin{tabular}{ccccccccc}
\hline Populations & N & M & NPB & PPB & Ao & Ae & H & I \\
\hline Curitiba & 23 & 23 & 130 & 81.76 & 1.82 & 1.39 & 0.24 & 0.37 \\
Palmeira & 24 & 23 & 121 & 76.10 & 1.76 & 1.33 & 0.21 & 0.33 \\
São Luiz Purunã & 26 & 25 & 111 & 69.81 & 1.70 & 1.33 & 0.20 & 0.31 \\
Total & 73 & 70 & 155 & 97.48 & 1.97 & 1.39 & 0.25 & 0.40 \\
\hline
\end{tabular}

$\mathrm{N}=$ numbers of individuals; $\mathrm{M}=$ numbers of polymorphic individuals; NPB = numbers of polymorphic bands; $\mathrm{PBP}=\%$ polymorphic bands; $\mathrm{Ao}=$ observed number of alleles; $\mathrm{Ae}=$ expected number of alleles; $\mathrm{H}=$ Nei's gene diversity; $\mathrm{I}$ = Shannon's information index.

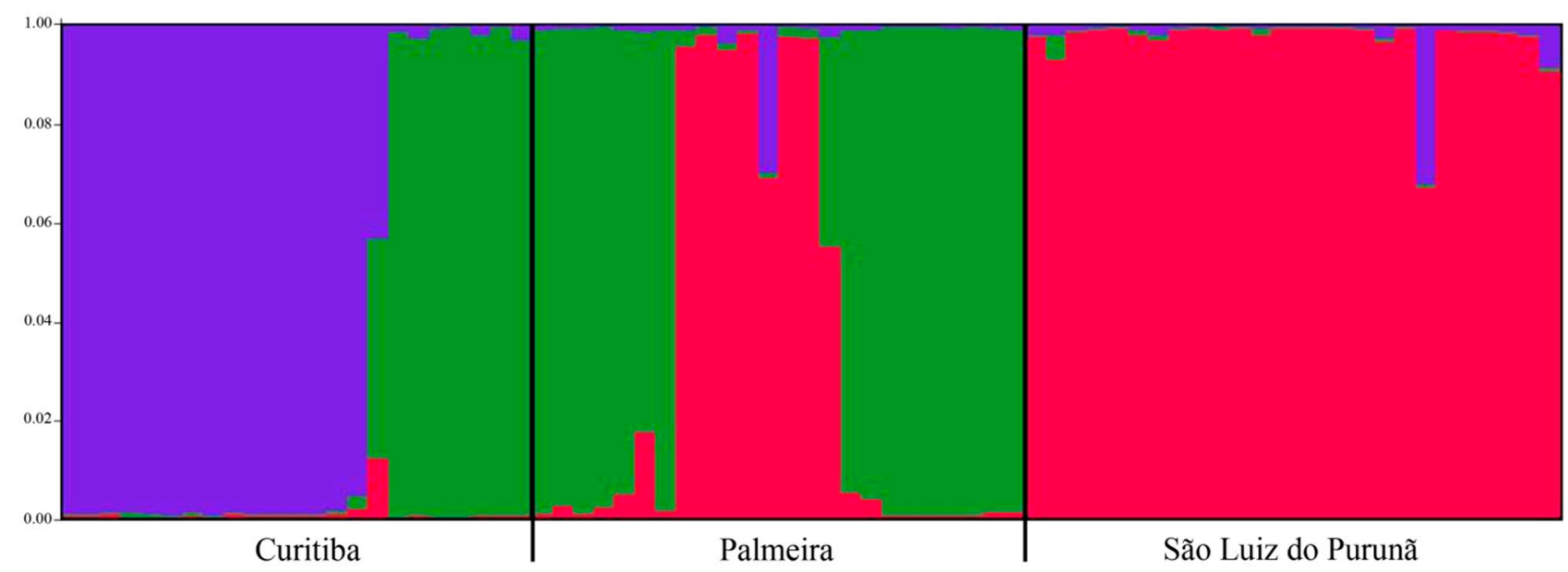

Figure 4. Estimated geographic group structure for three populations of Salvia lachnostachys Benth. with ISSR markers. Different greyscale colors indicate different geographic groups (Palmeira, São Luiz do Purunã, Curitiba). Long black lines indicate the separation among a priori assigned groups. 


\section{Discussion}

The chemical composition of Salvia strongly indicates that the herb has potential to become an important raw material for anti-inflammatory compounds and knowledge of the diversity of wild populations will therefore be important to inform the use and conservation of this genus. Genetic surveys, in particular, are key measures to efficiently access the genetic resources of species of pharmacological interest.

Several markers have been previously applied to survey genetic variability within the genus Salvia [23-25]. Specifically, there are some important publications addressing S. miltiorrhiza, most of them utilizing dominant markers [23-27].

Despite the increasing human pressure on natural areas in Brazil, the Salvia species (S. lachnostachys) used in our study had high levels of genetic variability (PPB $=97.48 \%, \mathrm{I}=0.3982$ ). This result suggests that the species is relatively resilient, and provides a good opportunity to study, collect and conserve $S$. lachnostachys diversity, including the use of germplasm banks. Such actions would reduce the diversity loss and genetic erosion found in cultivated species, which typically have lower diversity associated with human assisted propagation and germplasm exchange [23,28].

When considered alongside the Simpson index, the sampling variance values suggest an acceptable level of precision using the selected primers (Table 2). Based on the level of polymorphism detected, these primers may therefore represent a useful starting point for further population studies in Salvia. Nevertheless, the inclusion of a greater number of markers would presumably further increase the value of the Simpson index.

Wild populations of S. miltiorrhiza were previously evaluated using AFLPs [29]. The average Nei's gene diversity index found $(\mathrm{H}=0.2612)$ was very consistent with that observed in the present evaluation of wild $S$. lachnostachys $(\mathrm{H}=0.2509)$. Comparisons with a cultivated population of S. miltiorrhiza reveal a lower average value of Nei's gene diversity index $(\mathrm{H}=0.1951)$ [23]. However, it is important to remember for these comparisons that Nei's gene diversity index is an estimate of the expected heterozygosity. In the current study, considering a dominant marker, the gene diversity is derived from the calculated expected allele frequencies. Thus, the index is somewhat limited and its precision relies on the validity of the Hardy-Weinberg assumption. For this reason, comparisons of Nei's gene diversity values from studies using different marker classes should not be made directly. For both previously cited studies in Salvia [23,29], dominant markers were used (RAPD and ISSR respectively). Another issue related to comparisons of Nei's gene diversity is that different markers have different abilities to recover polymorphisms. For example, many authors have noted that ISSR markers detect higher number of polymorphic loci than isozymes and RAPD methods [28,30,31]. Therefore, the index should be considered an indicative, and comparisons should always consider these differences. The Shannon diversity index values are consistent with the population and species level genetic variability.

The unrooted dendrogram obtained in the cluster analysis effectively discriminated the sampled localities in distinct clusters based on Nei and Li distances. The dendrogram suggests a consistent differentiation among the sampled populations. The high genetic variability maintained within populations is encouraging. However, the division of samples from Palmeira in two distinct clusters was not expected; this may be related to many causes, such as founder effects or restricted gene flow. The value $G_{s t}$ in $S$. lachnostachys was 0.1678 indicating that greater variation exists within populations 
than among populations. This result is consistent with that found for $S$. miltiorrhiza $\left(G_{s t}=0.1336\right)$. Many factors contribute to genetic structure in plant populations, especially reproductive biology, gene flow, seed dispersal and nature selection. In particular, reproductive biology plays a central role in the genetic structure [32]. It is conceivable that the outcrossing strategy previously recorded for Salvia [33] is responsible for the higher observed diversity within populations. This is particularly probable with high population densities where outcrossing rates are higher.

The high adaptability and wide distribution of $S$. lachnostachys in the study area may also contribute to the low levels of differentiation between populations. Specifically, a high number of migrants $\mathrm{Nm}$ ) may facilitate gene exchange between populations. Vegetative reproduction (sprouting) may also reintroduce genes after an extinction event (e.g., fire) in a single sub-population. However, the most important mechanism promoting gene flow in natural populations of plants is through the spread of seeds and pollen [34] and it is possible that prevailing winds connect the populations in the study areas. Moreover, there are several main roads crossing these areas that may act as corridors for insects, the main pollinators of Salvia species. The exchange of genetic material has been observed in other Salvia species; the $\mathrm{Nm}$ in S. miltiorrhiza was 3.2362 [23]. This value is similar to that observed in the present study (2.4806). This level of migration may be sufficient to partially counteract the genetic differentiation caused by genetic drift within single populations explaining the low differentiation among them [35]. Nevertheless, the results generated from Structure for all the populations indicated a value of $\mathrm{K}=3$, indicating that it is possible to distinguish three genetically different groups with genotypes attributed according to geographical origin. Structure assignment helped to clarify the topology found in UPGMA unrooted dendrogram. Samples 17 to 23 (collected in Curitiba) were indicated by the Bayesian admixture analysis as similar to genotypes collected from Palmeira and samples 31-38 (collected in Palmeira) were indicated as similar to genotypes from São Luiz do Purunã supporting the perceived pattern of high gene exchange and low genetic differentiation among populations.

\section{Experimental Section}

\subsection{Sampling and DNA Extraction}

Field sampling covered the restricted distribution of S. lachnostachys in Parana State, southern Brazil. The geomorphological profile for this State consists of an Atlantic coastal plain at its eastern limits followed by a mountain ridge and three consecutive plateaus corresponding, respectively, to Curitiba, Ponta Grossa and Guarapuava city regions. Populations of S. lachnostachys occur mainly on the Curitiba and Ponta Grossa plateaus. Three populations S. lachnostachys were chosen to represent the restricted distribution (Table 3, Figure 5). Our choice was based on the geographic distribution and topographic features. A voucher specimen for each population was deposited in UPCB Herbarium, Federal University of Paraná, Curitiba, Brazil (Table 3).

Table 3. Location and samples size of three populations of Salvia lachnostachys Benth.

\begin{tabular}{cccccc}
\hline Location & Latitude S & Longitude W & Altitude (m) & Voucher Number & No. of Samples \\
\hline Curitiba & $25^{\circ} 30^{\prime} 22^{\prime \prime}$ & $49^{\circ} 18^{\prime} 30^{\prime \prime}$ & 932 & E.P. Santos 1251 & 23 \\
Palmeira & $25^{\circ} 28^{\prime} 10^{\prime \prime}$ & $49^{\circ} 48^{\prime} 05^{\prime \prime}$ & 1069 & E.P. Santos 1264 & 24 \\
São Luiz do Purunã & $25^{\circ} 28^{\prime} 13^{\prime \prime}$ & $49^{\circ} 39^{\prime} 33^{\prime \prime}$ & 1089 & E.P. Santos 1266 & 26 \\
\hline
\end{tabular}




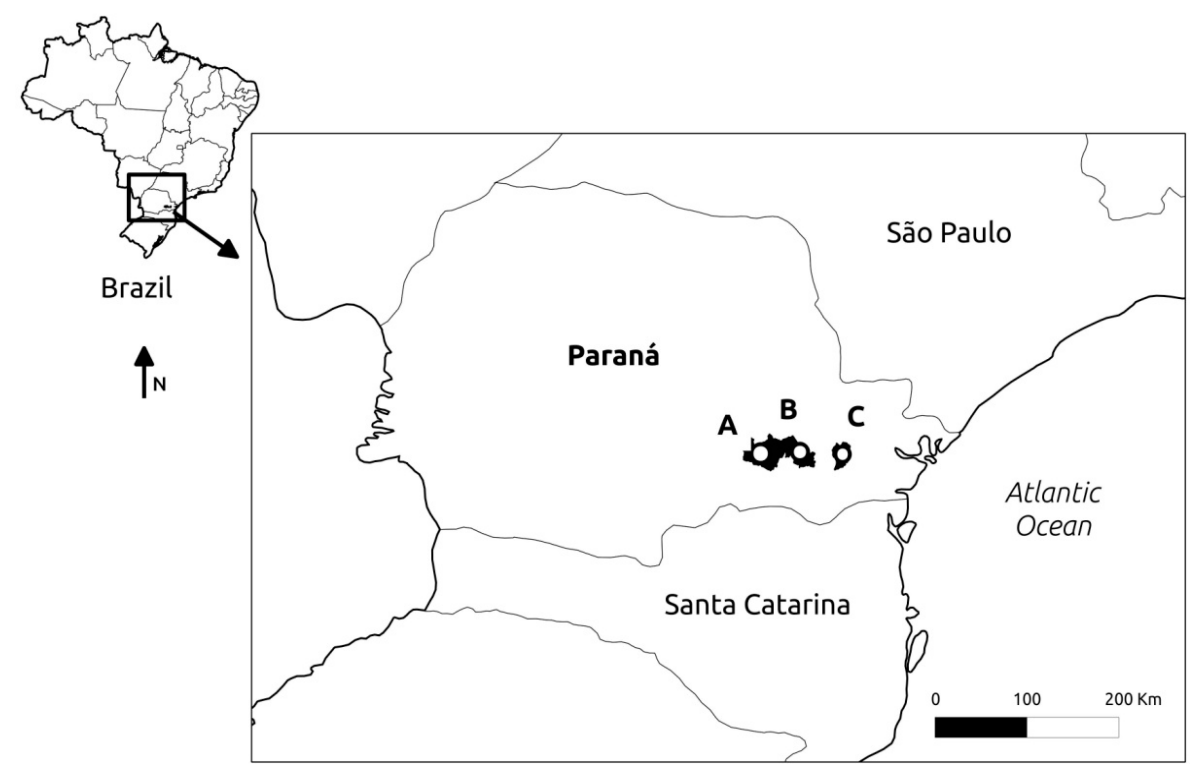

Figure 5. Locations of the different populations of Salvia lachnostachys Benth. in Paraná State, Brazil; (A) Palmeira; (B) São Luiz do Purunã; (C) Curitiba.

Leaves of 73 individuals were collected and stored in CTAB gel (3\% Cationic Hexadecyl Trimethyl Bromide, 35\% NACl). Genomic DNA was extracted using the modified $2 \times$ CTAB method by Doyle and Doyle. DNA integrity was examined in $1 \%$ agarose gel buffered with $1 \times$ TBE (tris-borate-EDTA buffer). Quality and concentration was doubled checked with a fluorimeter and a mass ladder comparison. Samples were kept in $-20{ }^{\circ} \mathrm{C}$ until ISSR PCR processing.

\subsection{ISSR-PCR Amplification}

Nine previously tested primers for $S$. lachnostachys with good repetition and distinct polymorphic bands were chosen based on the existing literature (Table 1). ISSR-PCR reactions were carried out in a final $20 \mu \mathrm{L}$ reaction volume containing $1.5 \mathrm{mM} \mathrm{MgCl}_{2}, 0.2 \mathrm{mM}$ of each dNTP, $2 \mu \mathrm{L}$ of $10 \times \mathrm{TAQ}$ buffer (Fermentas, Vilnius, Lithuania), $0.6 \mu \mathrm{M}$ primer, 2\% DMSO (dimethylsulphoxide), 1U Taq DNA polymerase, and 1-2 ng/ $\mu \mathrm{L}$ of template DNA. Amplification was performed in an Mastercycler Gradient (Eppendorf, Hamburg, Germay) under the following conditions: initial denaturation at $94{ }^{\circ} \mathrm{C}$ for $2 \mathrm{~min}$; then 35 cycles of $94{ }^{\circ} \mathrm{C}$ for $1 \mathrm{~min}$, annealing at optimal temperature (Table 1) for $45 \mathrm{~s}$, and $72{ }^{\circ} \mathrm{C}$ for $2 \mathrm{~min}$; and a final extension at $72{ }^{\circ} \mathrm{C}$ for $7 \mathrm{~min}$. The negative control used for each amplification consisted of a regular reaction tube without template DNA. In this case, the template DNA was replaced by an equal volume of $\mathrm{ddH}_{2} \mathrm{O}$. PCR products were separated by electrophoresis using $1.5 \%$ agarose gel in $1 \times$ TAE (Tris-acetate-EDTA buffer), visualized with $4 \%$ ethidium bromide under ultraviolet light and photographed by $2 \mathrm{UV}$ Benchtop Transilluminator (UVP, Ultra-Violet Products Ltd., Cambridge, UK).

\subsection{Data Analysis}

ISSR data are dominant and, therefore, each band represents the genotype at a single bi-allelic locus. Samples were processed in three independent amplifications for each primer. All the electrophoresis photographic files were electronically analyzed (GelAnalyzer). Average bands size was 
computed and homology was inferred when size values were within a $2 \%$ range of error (considering their assigned size). Only fragments in the size range of $220 \mathrm{bp}$ to $2.2 \mathrm{~kb}$ were included. The phenotypic pattern of the 73 individuals for all primers was recorded in a single binary matrix.

Sampling variances were examined to determine how many markers would be required for a given level of precision in the estimate of genetic distances [36,37]. The procedure was done within the software GENES version 2009.7.0 [38] using 1 to 159 markers and considering similarity under Nei and Li [39]. Ideal number of polymorphic bands was considered based on the suggested $<0.05$ stress value [40].

Simpson's index was calculated by using the following formulas: $S=\operatorname{Sum}\left(1-\operatorname{sum} f^{\wedge} 2\right) / N$. Genetic variability within and among populations was evaluated using the percentage of polymorphic bands $(P P B)$, observed number of alleles $(A o)$, effective number of alleles $(A e)$, Nei's gene diversity $(\mathrm{He})$ and Shannon's information index $(I)$ using PopGene version 3.2 [41]. Estimates of gene flow $(\mathrm{Nm})$ were calculated following McDermott and McDonald [42]. Analysis of molecular variance (AMOVA) was used to estimate the partitioning of genetic variance among and within populations from different geographical origin with GenAlEx 6.4 software [43] and Arlequin version 3.11 [44]. Genetic relationships between populations were calculated using Nei's unbiased genetic distance (D). The cluster analysis of different geographical groups was carried out using Unweighted Pair-group Method using Arithmetic average (UPGMA), and the dendrogram was constructed by the programs NTSYSpc [45] and PAUP*4b10 [46]. As gene substitution rate is not constant, we also implemented a parsimony heuristic search. To visualize genetic relationships among all ISSR phenotypes, their pairwise Euclidean distances were subjected to principal components analysis (PCA) as implemented in NTSYSpc [45]. A Bayesian analysis of ISSR population structure was performed on the entire data set using the program STRUCTURE version 2.1 [47]. Assuming maximal 10 population clusters (K), 10 independent runs of $\mathrm{K}=1-10$ were performed at $10^{5}$ Markov chain Monte Carlo samplings after a burn-in period of $5 \times 10^{4}$ iterations - following the program's dominant marker settings, the "no admixture" model was used and uncorrelated allele frequencies among populations were assumed. The most likely number of clusters was estimated according to the model value $(\Delta K)$ based on the second order rate of change, with respect to $\mathrm{K}$, of the likelihood function, following the procedure described by Evanno et al. [48].

\section{Conclusions}

To effectively conserve genetic variability in a germplasm bank, priority should be given to both the clusters of populations in the Palmeira locality. The dendrogram and Bayesian analysis indicate that this population is related to samples from Curitiba and São Luiz do Purunã. As the genetic variability is higher within populations and differences among the three examined populations are low, diversity could be maximized by concentrating sampling within the population from Palmeira.

\section{Acknowledgments}

We acknowledge the financial support and fellowships from National Counsel of Technological and Scientific Development $(\mathrm{CNPq})$ and Coordenação de Aperfeiçoamento de Pessoal de Nível Superior (CAPES/Reuni). 


\section{Author Contributions}

Conception and design: Élide Pereira dos Santos. Sample collection: Élide Pereira dos Santos, Marianna Erbano. Experiment: Marianna Erbano. Data analysis and drafting of the manuscript: Élide Pereira dos Santos, Marianna Erbano, Guilherme Schnell e Schühli. Critical revisions/supervision: Élide Pereira dos Santos, Guilherme Schnell e Schühli.

\section{Conflicts of Interest}

The authors declare no conflict of interest.

\section{References}

1. Harley, R.M.; Atkins, S.; Budantsev, A.L.; Cantino, P.D.; Conn, B.J.; Grayer, R.; Harley, M.M.; Kok, R.; Krestovsaja, T.; Morales, R.; et al. Labiatae. In The Families and Genera of Vascular Plant; Kadereit, J.W., Kubitzki, K., Eds.; Springer-Verlag: Berlin, Germany, 2004; Volume 7, pp. 167-236.

2. Santos, E.P. Salvia L. In Lista de Espécies da Flora do Brasil. Available online: http://www.floradobrasil.jbrj.gov.br/jabot/floradobrasil/FB8296 (accessed on 19 December 2014).

3. Cheng, T.O. Cardiovascular effects of Danshen. Int. J. Cardiol. 2007, 121, 9-22.

4. Hosseinzadeh, H.; Haddakhodaparast, M.H.; Arash, A.R. Antinociceptive, antiinflammatory and acute toxicity effects of Salvia leriifolia Benth. seed extract in mice and rats. Phytother. Res. 2003, 17, 422-425.

5. Mayer, B.; Baggio, C.H.; Freitas, C.S.; Santos, C.; Twardowschy, A.; Horst, H.; Pizzolatti, M.G.; Micke, G.H.; Heller, M.; Santos, E.P.; et al. Gastroprotective constituents of Salvia officinalis L. Fitoterapia 2009, 80, 421-426.

6. Fan, H.Y.; Fu, F.H.; Yang, M.Y.; Xu, H.; Zhang, A.H.; Liu, R. Antiplatelet and antithrombotic activities of salvianolic acid A. Thromb. Res. 2010, 126, 17-22.

7. Veitch, N.C.; Smith, M.; Barnes, J.; Anderson, L.A.; Phillipson, J.D. Herbal Medicines, 4th ed.; Pharmaceutical Press: London, UK, 2013.

8. Jimena, E.S.; França, F.; Sobral, M. Plantas da Floresta Atlântica; Jardim Botânico do Rio de Janeiro: Rio de Janeiro, Brazil, 2009; pp. 297-303.

9. Erbano, M.; Ehrenfried, C.A.; Stefanello, M.E.A.; Santos, E.P. Morphoanatomical and phytochemical studies of Salvia lachnostachys (Lamiaceae). Microsc. Res. Techniq. 2012, 75, 1737-1744.

10. Kassuya, C.A.L.; Wisniewski-Junior, A.; Simionatto, E.L.; Santos, E.P.; Stefanello, M.E.A. Composição dos óleos essenciais de Salvia lachnostachys e Salvia melissiflora (Lamiaceae). Lat. Am. J. Pharm. 2009, 28, 919-921.

11. Piccinelli, A.C.; Aquino, D.F.S.; Morato, P.N.; Kuraoka-Oliveira, A.M.; Strapasson, R.L.B.; Santos, E.P.; Stefanello, M.E.A.; Oliveira, R.J.; Kassuya, C.A.L. Anti-inflammatory and antihyperalgesic activities of ethanolic extract and fruticulin A from Salvia lachnostachys leaves in mice. Evid. Based Complement. Alternat. Med. 2014, 2014, doi:10.1155/2014/835914.

12. Gupta, V.S.; Ramakrishna, W.; Rawat, S.R.; Ranjekar, P.K. (CAC)5 detects DNA fingerprinting and sequence homologous to gene transcripts in rice. Biochem. Genet. 1994, 32, 1-8. 
13. Barth, S.; Melchinger, A.E.; Lübberstedt, T.H. Genetic diversity in Arabidopsis thaliana L. Heynh. investigated by cleaved amplified polymorphic sequence (CAPS) and inter-simple sequence repeat (ISSR) markers. Mol. Ecol. 2002, 11, 495-505.

14. Bornet, B.; Branchard, M. Nonanchored Inter Simple Sequence Repeat (ISSR) markers: Reproducible and specific tools for genome fingerprinting. Plant Mol. Biol. Rep. 2001, 9, 209-215.

15. Bai, C.; Wen, M.; Zhang, L.; Li, G. Genetic diversity and sampling strategy of Scutellaria baicalensis germplasm resources based on ISSR. Genet. Resour. Crop. Evol. 2013, 60, 1673-1685.

16. Qian, X.; Li, Q.J.; Liu, F.; Gong, M.J.; Wang, C.X.; Tian, M. Conservation genetics of an endangered Lady's Dlipper Orchid: Cypripedium japonicum in China. Int. J. Mol. Sci. 2014, 15, 11578-11596.

17. Kurane, J.; Shinde, V.; Harsulkar, A. Application of ISSR marker in pharmacognosy: Current update. Pharmacogn. Rev. 2009, 3, 216-228.

18. Lüdtke, R.; Agostini, G.; Miotto, S.T.S.; Souza-Chies, T.T. Characterizing Polygala L. (Polygalaceae) species in Southern Brazil using ISSR. Plant Mol. Biol. Rep. 2010, 28, 317-323.

19. Mittermeier, R.A.; Fonseca, G.A.B.; Rylands, A.B.; Brandon, K. Uma breve história da conservação da biodiversidade do Brasil. Megadiversidade 2005, 19, 601-607.

20. Agostini, G.; Echeverrigaray, S.; Souza-Chies, T.T. Genetic relationships among South American species of Cunila D. Royen ex L. based on ISSR. Plant Syst. Evol. 2008, 274, 135-141.

21. Fracaro, F.; Echeverrigaray, S. Genetic variability in Hesperozygis ringens Benth. (Lamiaceae), an endangered aromatic and medicinal plant of Southern Brazil. Biochem. Genet. 2006, 44, 479-490.

22. Rahimmalek, M.; Bahreininejad, B.; Khorrami, M.; Tabatabaei, B.E.S. Genetic variability and geographic differentiation in Thymus daenensis subsp. daenensis, an endangered medicinal plant, as reaveled by inter simple sequence repeat (ISSR) markers. Biochem. Genet. 2009, 47, 831-842.

23. Song, Z.; Li, X.; Wang, H.; Wang, J. Genetic diversity and population structure of Salvia miltiorrhiza Bge in China revealed by ISSR and SRAP. Genetica 2010, 138, 241-249.

24. Javan, Z.S.; Rahmani, F.; Heidari, R. Assessment of genetic variation of genus Salvia by RAPD and ISSR markers. Aust. J. Crop. Sci. 2012, 6, 1068-1073.

25. Zhang, Y.; Li, X.; Wang, Z. Diversity evaluations of Salvia miltiorrhiza using ISSR markers. Biochem. Genet. 2013, 51, 707-721.

26. Guo, B.L.; Lin, S.; Feng, Y.X.; Zhao, Y.J. Primary research on genetic relationship among main populations of Salvia miltiorrhiza and genuineness of herb. Zhongcaoyào 2002, 33, 1113-1116.

27. Wang, Q.; Zhang, B.; Lu, Q. Conserved region amplification polymorphism (CoRAP), a novel marker technique for plant genotyping in Salvia miltiorrhiza. Plant Mol. Biol. Rep. 2009, 27, 139-143.

28. Ge, X.J.; Sun, M. Reproductive biology and genetic diversity of a cryptoviviparous mangrove Aegiceras corniculatum (Myrsinaceae) using allozyme and intersimple sequence repeat (ISSR) analysis. Mol. Ecol. 1999, 8, 2061-2069.

29. Wang, B.; Zhang, Y.; Chen, C.B.; Li, X.L.; Chen, R.Y.; Chen, L. Analysis on genetic diversity of different Salvia miltiorrhiza geographical populations in China. Zhongguo Zhong Yao Za Zhi 2007, 32, 1988-1991.

30. Wolfe, A.D.; Liston, A. Contributions of PCR-based methods of plant systematics and evolutionary biology. In Molecular Systematics of Plants II: DNA Sequencing; Soltis, P.S., Soltis, D.E., Doyle, J.J., Eds.; Springer Science + Business Media: New York, NY, USA, 1998; pp. 43-86. 
31. Camacho, F.J.; Liston, A. Population structure and genetic diversity of Botrychium pumicola (Ophioglossaceae) based on Inter-Simple Sequence Repeats (ISSR). Am. J. Bot. 2001, 88, 1065-1070.

32. Zhao, Y.; Chen, X.Y.; Wang, X.R.; Pian, R.Q. ISSR analysis of genetic diversity among Lespedeza bicolor populations. J. Plant Genet. Resour. 2007, 8, 195-199.

33. Bijlsma, R.; Ouborg, N.J.; Treuren, R. On genetic erosion and population extinction in plants: A case study in Scabiosa columbaria and Salvia pratensis. Conserv. Genet. 1994, 68, 255-271.

34. Li, H.; Chen, G. Genetic diversity of mangrove plant Sonneratia caseolaris in Hainan Island based on ISSR analysis. Acta Ecol. Sin. 2004, 24, 1656-1662.

35. Wang, J. Application of the one migrant per generation rule of conservation and management. Conserv. Biol. 2004, 18, 332-343.

36. Tivang, J.G.; Nienhuis, J.; Smith, O.S. Estimation of sampling variance of molecular marker data using the bootstrap procedure. Theor. Appl. Genet. 1994, 89, 259-264.

37. Manly, B.F.J. Randomization, Bootstrap and Monte Carlo Methods in Biology, 2nd ed.; Chapman \& Hall/CRC: London, UK, 1997.

38. Cruz, C.D. Programa Genes—Biometria; Editora UFV: Viçosa, Brazil, 2006.

39. Nei, M.; Li, W.H. Mathematical model for studying genetic variation in terms of restriction endonucleases. Proc. Natl. Acad. Sci. USA 1979, 76, 5269-5273.

40. Kruskal, J.B. Nonmetric multidimensional scaling: A numerical method. Psychometrika 1964, 29, $115-129$.

41. Yeh, F.C.; Yang, R.; Boyle, T. PopGene version 3.2: Microsoft Window-Based Freeware for Population Genetic Analysis. University of Alberta: Edmonton, AB, Canada, 1999.

42. McDermott, J.M.; McDonald, B.A. Gene flow in plant pathosystems. Annu. Rev. Phytopathol. 1993, 31, 353-373.

43. Peakall, R.; Smouse, P.E. GENEALEX 6: Genetic analysis in Excel. Population genetic software for teaching and research. Mol. Ecol. Notes 2006, 6, 288-295.

44. Excoffier, L.; Laval, G.; Schneider, S. Arlequin (version 3.0): An integrated software package for population genetics data analysis. Evol. Bioinform. Online 2005, 1, 47-50.

45. Rohlf, F.J. NTSYS-pc: Numerical Taxonomy and Multivariate Analysis System, Version 2.1; Exeter Sotfware: New York, NY, USA, 2000.

46. Swofford, D.L. PAUP* Phylogenetic Analysis Using Parsimony (*and Others Methods), Version 4b10; Sinauer Associates: Sunderland, MA, USA, 2003.

47. Pritchard, J.K.; Stephens, M.; Donnelly, P. Inference of population structure using multilocus genotype data. Genetics 2000, 155, 945-959.

48. Evanno, G.; Regnaut, S.; Goudet, J. Detecting the number of clusters of individuals using the software STRUCTURE: A simulation study. Mol. Ecol. 2005, 14, 2611-2620.

(C) 2015 by the authors; licensee MDPI, Basel, Switzerland. This article is an open access article distributed under the terms and conditions of the Creative Commons Attribution license (http://creativecommons.org/licenses/by/4.0/). 